\title{
Production of probiotic Mozzarella cheese by incorporating locally isolated Lactobacillus acidophilus
}

\author{
Hamid Mukhtar ${ }^{*}$, Saima Yaqub and Ikram ul Haq
}

\begin{abstract}
Purpose: The present study was conducted to isolate and screen the potential probiotic strains for incorporation in Mozzarella cheese.

Methods: Probiotic cultures were isolated from different randomly purchased yogurt samples and were identified as Lactobacillus sp., Bifidobacteria sp., and Pediococcus sp. after morphological and biochemical characterization. Heat tolerance of isolates was tested at $55^{\circ} \mathrm{C}$ and $65^{\circ} \mathrm{C}$ to determine the survival of isolates in conditions similar to commercial cheese production. Lactobacillus acidophilus (S2) showed remarkable heat tolerance among all strains and was therefore selected to assess the probiotic potential. It showed good survival at acidic pH values (2-3). Moreover, it also showed $>50 \%$ tolerance to bile salt and was resistant to antibiotics, chloramphenicol, tetracycline, gentamycin, and vancomycin and also exhibited anti-microbial activity against Salmonella typhimurium, Escherichia coli, and Staphylococcus aureus. Thus, heat-tolerant Lactobacillus acidophilus (S2) isolate was an ideal strain for incorporation in Mozzarella cheese as probiotics. Three types of cheeses viz., cheese A with free cells of Lactobacillus acidophilus (S2), cheese B with encapsulated cells of Lactobacillus acidophilus (S2), and control cheese having no probiotics, were made.

Result: Microbiological analysis of prepared cheese revealed lesser loss of Lactobacillus acidophilus (S2) from encapsulated form $\left(3.41 \times 10^{8} \mathrm{CFU} / \mathrm{mL}\right)$ compared to free cells of Lactobacillus acidophilus (S2) $\left(1.10 \times 10^{7} \mathrm{CFU} / \mathrm{mL}\right)$. Coliforms were observed in control cheese after 10 days of storage, whereas no coliforms were observed in cheese $A$ and cheese B even after 15 days of storage. Organoleptic properties of cheese A and cheese B were almost the same with an acceptability score of $2.7 \pm 0.1$ and $2.65 \pm 0.1$, respectively. Control cheese got the lowest scores after 15 days of storage.
\end{abstract}

Conclusion: The addition of probiotics in cheese not only prolongs the shelf-life of cheese but also increases the organoleptic properties of the cheese, making cheese a good delivery system for probiotics.

Keywords: Probiotics, Lactobacillus, Yogurt, Quality assessment, Cheese

\section{Introduction}

Probiotic food products are gaining popularity among consumers due to health benefits. Such foods are not only nutritionally dense but also decrease the risk of different diseases (Mahrous et al. 2014). According to

\footnotetext{
* Correspondence: hamidmukhtar@gcu.edu.pk

* Correspondence: hamidmukhtar@gcu.edu.pk
Institute of Industrial Biotechnology, Government College University, Lahore 54000, Pakistan
}

(c) The Author(s). 2020 Open Access This article is licensed under a Creative Commons Attribution 4.0 International License, which permits use, sharing, adaptation, distribution and reproduction in any medium or format, as long as you give

appropriate credit to the original author(s) and the source, provide a link to the Creative Commons licence, and indicate if changes were made. The images or other third party material in this article are included in the article's Creative Commons licence, unless indicated otherwise in a credit line to the material. If material is not included in the article's Creative Commons licence and your intended use is not permitted by statutory regulation or exceeds the permitted use, you will need to obtain permission directly from the copyright holder. To view a copy of this licence, visit http://creativecommons.org/licenses/by/4.0/.

FAO (Food and Agriculture Organization of the United Nations) "Probiotics are living microorganisms which, when administered at adequate levels $\left(10^{6}\right.$ to $10^{7} \mathrm{CFU} /$ g), confer health benefits to the host" (FAO/WHO 2006). Thus, the therapeutic benefits of these products increase the consumption of probiotics (Weichselbaum 2009). Probiotics have been associated with the control of gastrointestinaland urinary tract infections. Other benefits include improvement in lactose tolerance, 
reduction in serum cholesterol level, enhancement of host's immunity, and prevention of colon cancerantibioticassociated diarrhea and different allergic diseases (Bai and Ouyang 2006; Falagas et al. 2006; Krämer and Bischoff 2006; Sanders et al. 2007; O'Flaherty and Klaenhammer 2010; Yerlikaya 2014).

A majority of probiotics are bacteria, but yeasts may also be considered as probiotics because of their potential to survive in the digestive system and different health benefits to the host (Anal and Singh 2007; Senter et al. 2015). These health benefits are due to competition with pathogenic microbes, improvement in the host's immune system, production of acids, and antimicrobial proteins (Chen and Chen 2007). Probiotics are orally administered and are either incorporated in food products or in different non-food preparations, such as tablets, capsules, or sachets. Probiotic foods include dairy products, such as cheese, ice cream, dairy desserts, and yogurt, as well as non-dairy products, such as juices, cereals, and chocolates. Food products containing probiotic bacteria are known as "functional foods." Fermented functional foods have numerous health benefits due to incorporated probiotic microorganisms (Gobbetti et al. 2010). Viability of probiotic bacteria in a food product is influenced by many factors, such as acidity, post acidification, oxygen level of the product, penetration of oxygen through packaging, shortage of nutrients, and sensitivity to different antimicrobial substances produced by starter culture (Fortin et al., 2011).

Safety aspects include the origin of probiotic bacteria and the non-pathogenic nature of the strains. Functional aspects are related to survivability under the acidic conditions of human gastrointestinal tract and the ability to tolerate bile salts. Probiotics must attach and colonize to gastrointestinal epithelia and colonize there. They may also possess anti-carcinogenic and anti-mutagenic properties. Immunostimulation and antagonistic activity are some other functional aspects of probiotics. Good sensory properties, ability to be manufactured while staying viable and functional in the product, and survivability during storage till the end of shelf-life of the product without creating bad taste or textures are different technological aspects (Ortakci 2012; Senter et al. 2015).

There is an increase in the popularity and acceptance of functional foods throughout the world as they exert a positive impact on human health (Mattila-Sandholm et al. 2002). There is 7 to $32 \%$ increase in sales of different probiotic products each year on the basis of geographical locations and functions of probiotics (Helene et al. 2011). Mozzarella cheese is a prominent member of pasta filata cheeses, originating from Italy. Pasta filata cheeses are famous for their exceptional stretchability, shredability, and meltability which are due to unique texturing and plasticizing treatments of curd in hot water. It is made by chemical acidification or biological acidification using commercial starter cultures, such as Streptococcus thermophilus (Minervini et al. 2012).

Many challenges are involved in the production of probiotic Mozzarella cheese, such as survival of probiotic bacteria during cheese production and storage (Fortin et al., 2011) while maintenance of sensory characteristics of cheese is another challenge. Therefore, there is a need to incorporate thermophilic probiotic strains with good sensory attributes. Therefore, the present study was undertaken to isolate the potential probiotic strains and screen them for their optimal efficacy, followed by incorporation in the Mozzarella cheese. As per available literature, it is a first ever report on the production of probiotic Mozzarella cheese by incorporation of a probiotic strain of Lactobacillus acidophilus.

\section{Materials and methods}

\section{Isolation of microorganisms}

A total of ten separate samples of fresh traditional yogurts were collected from local markets of Lahore, Pakistan, and stored at $4{ }^{\circ} \mathrm{C}$ to avoid contamination and spoilage during transportation (Astashkina et al. 2014). Samples were immediately processed for microbiological analysis in the lab after collection. For isolation of microorganisms, we followed the protocol as described by Karami et al. (2017) with some modification. One gram of each sample was inoculated in $10 \mathrm{ml}$ of de Man, Rogosa, and Sharpe (MRS) broth tubes aseptically and incubated at $37^{\circ} \mathrm{C}$ for $48 \mathrm{~h}$ under anaerobic conditions. Anaerobic conditions were provided by anaerobic jar with a gas pack. Pour plate technique was used for getting well-isolated colonies from cultures. After incubation, serial dilutions of MRS broth were made in $0.1 \%$ peptone water. One hundred microliter of each dilution was poured on plates containing molten MRS agar medium [MRS broth $\left(55 \mathrm{gL}^{-1}\right), \mathrm{L}$ cysteine $\left(0.5 \mathrm{gL}^{-1}\right)$, and agar $\left.\left(55 \mathrm{gL}^{-1}\right)\right]$. All plates were incubated at $37^{\circ} \mathrm{C}$ for $48 \mathrm{~h}$ under anaerobic conditions. Colonies were purified by streaking repeatedly on MRS BPB agar [MRS broth $\left(55 \mathrm{gL}^{-1}\right)+\mathrm{L}$ cysteine $\left(0.5 \mathrm{gL}^{-1}\right)+$ Bromophenol blue $\left.\left(0.02 \mathrm{gL}^{-1}\right)+\operatorname{agar}\left(55 \mathrm{gL}^{-1}\right)\right]$ plates. Pure cultures were stored at $4{ }^{\circ} \mathrm{C}$ for further use.

\section{Physiochemical characterization of isolates}

Biochemical characterization of isolates was carried out through catalase test, indole test, gas production, sugar fermentation profile, $\mathrm{CaCO}_{3}$ utilization, and heat tolerance check (Holt et al. 1994). For the indole test, overnight culture (1\%) was added in $5 \mathrm{ml}$ of tryptophane broth and incubated at $37^{\circ} \mathrm{C}$ under anaerobic conditions. After $24 \mathrm{~h}, 5$ drops of Kovac's reagent were carefully added in tryptophane broth tubes and observed for the formation of a reddish-purple ring (Benson 
2002). Likewise, the fermentation behavior of isolates was evaluated by observing gas production. Cultures that did not produce gas within $48 \mathrm{~h}$ were considered to be homofermentative, while those which produced gas were considered heterofermentative (Barakat et al. 2011). Bromothymol blue broth ( $\mathrm{pH} 7$ ) was used to determine the fermentation profile of isolates with different added carbohydrates (glucose, fructose, sucrose, lactose, maltose, and mannitol) (Naeem et al. 2012), whereas $\mathrm{CaCO}_{3}$ utilization of isolates was observed on MRS agar with $\mathrm{CaCO}_{3}(0.8 \mathrm{~g} / 100 \mathrm{ml})$. Heat tolerance studies of the isolates were carried out by treating the cells at 65 and $55^{\circ} \mathrm{C}$ for $10 \mathrm{~min}$ and then culturing on MRS agar plates (Minervini et al. 2012).

Physiological characterization of heat-resistant isolates was executed by evaluating $\mathrm{NaCl}$ tolerance, variation in $\mathrm{pH}$ of inoculated skimmed milk, and phenol tolerance. $\mathrm{NaCl}$ tolerance of isolates was determined using various concentrations of $\mathrm{NaCl}(1-10 \%)$ in MRS broth tubes inoculated with microorganisms. After $24 \mathrm{~h}$, the bacterial count was determined by using a spectrophotometer (Hoque et al. 2010). For evaluation of variation in $\mathrm{pH}$ of skimmed milk, $10 \%$ sterilized skimmed milk tubes were inoculated with $1 \%(\mathrm{v} / \mathrm{v})$ overnight fresh culture, then incubated for $24 \mathrm{~h}$, and readings were taken after $0,3,6,9$, and $24 \mathrm{~h}$ using $\mathrm{pH}$ meter. For the measurement of phenol tolerance, phenol (0.4\%) was added in MRS broth and inoculated with $1 \%(\mathrm{v} / \mathrm{v})$ overnight fresh culture and incubated to check the inhibitory effect of phenol on isolated bacteria (Hoque et al. 2010).

\section{Assessment of probiotic potential of isolates}

The assessment of the probiotic potential of the selected isolate was performed by measuring acid tolerance, bile salt tolerance, antibiotic resistance, antimicrobial activity, and hemolytic activity (Pancheniak and Soccol 2005). To measure acid tolerance, Lactobacillus isolate was cultivated in MRS broth for $24 \mathrm{~h}$ at $37^{\circ} \mathrm{C}$ under anaerobic conditions. Cells were harvested and cultured in MRS broth tubes with different $\mathrm{pH}$ values, such as 1,2 , and 3 $\mathrm{pH}$ units. After 1,2 , and $4 \mathrm{~h}$ of incubation, bacterial suspension was diluted in $0.1 \%$ peptone water and was spread on MRS agar plates. Plates were incubated at $37^{\circ} \mathrm{C}$ under anaerobic conditions for $48 \mathrm{~h}$, and percent survival was determined (Patil and Vishwanath 2012).

For measuring bile salt tolerance, the potential probiotic isolate was cultivated in MRS broth supplemented with $2 \%$ bile salt at $37{ }^{\circ} \mathrm{C}$ under anaerobic conditions for $48 \mathrm{~h}$. Survival of the isolate was determined in terms of colony-forming units per milliliter (Patil and Vishwanath 2012). To assess the antibiotic resistance of the isolate, $100 \mu \mathrm{L}$ of overnight culture was spread on the MRS agar plate and incubated for $2 \mathrm{~h}$ at $37^{\circ} \mathrm{C}$. Then, antibiotic discs were placed on the plate and incubated under the same conditions for $48 \mathrm{~h}$. The zone of inhibition was determined, and isolate was referred as sensitive, intermediate, or resistant according to the size scale of antibiotics (Naeem et al. 2012). The anti-microbial activity of isolate was determined by using the well diffusion method (Shylaja et al. 2010). For hemolytic activity, blood agar plates [Nutrient broth $\left(13 \mathrm{gL}^{-1}\right)+$ agar $\left(15 \mathrm{gL}^{-1}\right)+$ sheep blood $\left.(5 \%)\right]$ were freshly prepared and streaked with the selected isolate and incubated at $37^{\circ} \mathrm{C}$ for $48 \mathrm{~h}$ under the anaerobic conditions. For beta hemolysis, zone formation was observed around the colonies. Staphylococcus aureus was used as a positive control.

\section{Microencapsulation of isolates}

A culture of the selected isolate was microencapsulated in alginate system using a method described by Sheu and Marshall (1993) with some modification. Cells of selected isolate $\left(\sim 10^{10} \mathrm{CFU} / \mathrm{mL}\right)$ was harvested by centrifugation at $10,000 \mathrm{rpm}$ for $10 \mathrm{~min}$ and washed twice with $0.1 \%$ saline water. The pellet was then added in the same amount of $4 \%(\mathrm{w} / \mathrm{v})$ sodium alginate solution and mixed thoroughly for $30 \mathrm{~min}$ at $4{ }^{\circ} \mathrm{C}$ using a magnetic stirrer. Thereafter, using a $10 \mathrm{~mL}$ sterile syringe, alginate and bacterial mixture was added drop by drop in $0.1 \mathrm{M} \mathrm{CaCl}_{2}$ solution. After $10 \mathrm{~min}$, beads were collected on filter paper and washed with saline water, blot dried with sterile filter paper, and stored at $4{ }^{\circ} \mathrm{C}$.

\section{Cheese production}

Pasteurized milk was supplemented with $1 \%$ of Streptococcus thermophilus along with rennet and mixed well. Then, the selected probiotic isolate was added in cheese in encapsulated and free form $\left(\sim 10^{10} \mathrm{CFU} / \mathrm{g}\right)$ and mixed well for $2 \mathrm{~min}$. Three types of cheeses, cheese A, cheese $\mathrm{B}$, and control cheese, were made. In control cheese, no probiotic was added, while in cheese A free cells of the probiotic organism were added, and in cheese B encapsulated cells of the probiotic strain were added. Then, cheeses were allowed to coagulate for $60 \mathrm{~min}$ until the curd got separated from whey. Curd was collected, broken, and laid over a table to drain for $20 \mathrm{~min}$. Hot brine $\left(70^{\circ} \mathrm{C}\right)$ was added to curd and mixed well until a homogenized paste was obtained. At $6^{\circ} \mathrm{C}$, the curd was added in iced brine (12\%) for $6 \mathrm{~h}$. After $4 \mathrm{~h}$, the curd was dried, and cheese was packed in sterile plastic bags and stored at $4{ }^{\circ} \mathrm{C}$ for further analysis (Sulieman et al. 2012).

\section{Microbiological analysis of cheese}

One gram of cheese was added in $10 \mathrm{~mL}$ of $0.1 \%$ peptone water and mixed well at $250 \mathrm{rpm}$ for $10 \mathrm{~min}$. Serial dilutions were made, and the probiotic bacteria were isolated using the pour plate technique. Encapsulated bacteria were enumerated by using phosphate buffer, 
diluted and plated on MRS BPB agar plates at $37{ }^{\circ} \mathrm{C}$ under anaerobic conditions for $48 \mathrm{~h}$. All samples were also cultured on McConkey agar for $24 \mathrm{~h}$ under aerobic conditions (Ortakci et al. 2012).

\section{Compositional analysis of cheese}

Compositional analysis of the cheese was performed as per the standard method of the Association of Analytical Chemists (AOAC 2000). To measure fat content in butyrometer, $10 \mathrm{~mL}$ of sulfuric acid was added, followed by the addition of $3 \mathrm{~mL}$ distilled water at $60{ }^{\circ} \mathrm{C}$. Cheese sample $(10 \mathrm{~g})$ was added in greaseproof paper and added in butyrometer; $5 \mathrm{ml}$ of water and $1 \mathrm{ml}$ of amyl alcohol were also added and mixed vigorously. The mixture was then centrifuged at $1300 \mathrm{rpm}$ for $5 \mathrm{~min}$. Hot water butyrometer was placed at $65^{\circ} \mathrm{C}$ for $3 \mathrm{~min}$ with the stopper facing downward, and the reading was taken by measuring the fat column.

For $\mathrm{pH}$ determination, $10 \mathrm{~g}$ of cheese sample was mixed with $6 \mathrm{~mL}$ of water and mixed thoroughly and then subjected to $\mathrm{pH}$ measurement. Moisture content of cheese was determined by the oven dry method. For salt content, $5 \mathrm{~g}$ of cheese sample and $100 \mathrm{~mL}$ of boiling water were added in a $250-\mathrm{mL}$ conical flask, swirled well, cooled till $55^{\circ} \mathrm{C}$, and then titrated against silver nitrate using potassium chromate as an indicator. Color change from pale yellow to buffered color was recorded as endpoint. Salt content was measured according to this formula:

Salt $\%(\mathrm{w} / \mathrm{w})=58.45 \times \mathrm{N} \times \mathrm{V} \times 100 / \mathrm{W} \times 100$

where "N" is the normality of silver nitrate, "V" is the weight of silver nitrate, and "W" is the weight of the sample.

\section{Organoleptic analysis}

Sensory analysis was done using 4-point hedonic scale (0-3). Six-membered panel was selected to evaluate the sensory attributes of cheeses based on their interest. Cheeses were taken out of the refrigerator and kept at room temperature for an hour. Then, cheese was sliced and served randomly for organoleptic analysis. Sensory attributes of experimental cheese included flavor, creamy nature, texture, and sour taste. A score of 3 was assigned to each attribute as follows: preferable (3), acceptable (2), needs modification (1), and not acceptable (0) (Minervini et al. 2012).

\section{Statistical analysis}

The experimental data was analyzed statistically using one way ANOVA by the method of Snedecor and Cochrane (1980) using a computer software CoStat 3.03 CoHort Software, Berkeley, CA 94701. Significance has been presented in the form of probability $(p \leq 0.05)$ values.

\section{Results and discussion}

Isolation and identification of probiotic bacteria

Probiotic bacteria were isolated from different locally produced yogurt samples. Out of 22 picked colonies, ten isolates with distinct colors and shapes were selected for further morphological and biochemical characterization.

Properly isolated colonies were picked up and transferred to solid media to observe their colony and cultural characteristics as described in Table 1. Seven isolates exhibited colony characteristics similar to the genus Lactobacillus as they appeared round, star-like, spindle-shaped, triangular, filiform, and irregular. Two isolates showed resemblance to the genus Bifidobacterium as they were round, creamy, convex spindle-shaped, and very soft in consistency. One isolate was found to be Pediococcus as colonies appeared round, raised, and smooth with small dotted-structure. Colony characteristics were better observed on MRS BPB agar as compared to MRS agar. Colonies showed different colors and various sizes on MRS BPB agar, whereas on MRS agar colonies were difficult to differentiate due to same color and size. Colonies of Lactobacilli appeared light blue while colonies of Bifidobacteria appeared dark blue on MRS BPB agar. The development of specific media has been tried by many researches for selective isolation of lactic acid bacteria (LAB), such as MRS agar (De Man et al. 1960), MRS clindamycin agar (Lankaputhra and Shah 1996), and LPSM (Bujalance et al. 2006). These media were appropriate to isolate specific $\mathrm{LAB}$ but not for isolation and selection of many lactic acid bacteria present as mixed culture in different foods. On MRS BPB agar, all LAB could easily grow, less incubation was required, and differentiation was easy (Lee and Lee 2008).

All isolates were characterized morphologically by Gram's staining, endospore staining, and motility test. They were found to be gram-positive and non-spore forming, and their morphological characteristics have been described (Table 2). Seven isolates resembled

Table 1 Colony characteristics of isolates

\begin{tabular}{lll}
\hline No & Isolates & Colony characteristics \\
\hline $\mathbf{1}$ & S1 & Round, convex, and smooth colonies \\
$\mathbf{2}$ & S2 & Round, raised with entire margin colonies \\
$\mathbf{3}$ & S3 & Round, flat smooth, and filiform colonies \\
$\mathbf{4}$ & S4 & Round and flat colonies \\
$\mathbf{5}$ & S5 & Round, regular, and smooth colonies \\
$\mathbf{6}$ & S6 & Round and convex colonies \\
$\mathbf{7}$ & S7 & Raised, small dot type colonies \\
$\mathbf{8}$ & S8 & Round and raised colonies \\
$\mathbf{9}$ & S9 & Triangular and raised colonies \\
$\mathbf{1 0}$ & S10 & Round and raised spindle shaped colonies \\
\hline
\end{tabular}


Table 2 Morphological characteristics of isolates

\begin{tabular}{llllll}
\hline Sr. no & Isolates & Gram's staining & Endospore staining & Motility test & Cell shape \\
\hline 1 & S1 & + & - & - & Thin rod shaped cells, branched, and $v$ and $Y$ arrangement in chains \\
2 & S2 & + & - & - & Thin rod shaped cells in chains with square ends \\
3 & S3 & + & - & - & Thin rod shape cells in long chains \\
4 & S4 & + & - & - & Regular rod shape cells in short chains \\
5 & S5 & + & - & - & Single rods \\
6 & S6 & + & - & - & Club shaped \\
7 & S7 & + & - & - & Cells spherical, tetrad, also in pairs \\
8 & S8 & + & - & - & Rod shape cells \\
9 & S9 & + & - & - & Rod shape cells as pairs \\
10 & S10 & + & - & - & Rods \\
\hline
\end{tabular}

+ Positive, - Negative

morphological characteristics of Lactobacilli, namely, S2, S3, S4, S5, S8, S9, and S10. Two isolates, namely, S1 and S6, were found to typically resemble the genus Bifidobacterium, i.e., gram-positive rods in "V" and "Y" arrangements, and club-shaped cells were observed under the microscope. Among them, one isolate, S7, resembled Pediococcus as cells were gram-positive diplococci and tetrad in arrangement. All the isolates were non-motile as they showed growth in stab line in spite of making whole media turbid.

LAB, especially Lactobacilli, are found in the gastrointestinal tract of human beings and animals. They are also present in milk and other dairy products (Jose et al. 2015). Hoque et al. (2010) isolated gram-positive nonspore-forming and non-motile Lactobacillus from yogurt, such as S2, S3, S4, S5, S8, S9, and S10 isolates. Zinedine and Faid (2007) isolated and characterized different Bifidobacteria from different sources, such as fermented foods, bovine meat, and fecal matter. They found that Bifidobacteria were in "V" and "Y" shape arrangements and were gram-positive. In the present study, S1 and S6 isolates showed similar characteristics. Sukumar and Ghosh (2010) isolated Pediococcus which had gram-positive cocci-shaped cells arranged in tetrads from khadi, a traditional fermented food; S7 showed similar characteristics and belonged to the genus Pediococcus.

All the purified strains were subjected to different biochemical tests. They were catalase-negative, showing that the catalase enzyme was absent in all isolates. None of the isolates produced indole, indicating that they were all indole-negative as well (Table 3). All isolates were homofermentative in nature as no gas production was observed in Durham's tubes. The ability of isolates to ferment different sugars was also observed by change of media color from blue to yellow. Isolates S1 and S2 were able to ferment all sugars, such as glucose, sucrose, fructose, maltose, and lactose expect for fructose; isolate "S7" showed the same fermentation as "S2" except for mannitol

Table 3 Biochemical characterization of isolates

\begin{tabular}{|c|c|c|c|c|c|c|c|c|c|c|}
\hline No & Isolates & Catalase & Indole & Gas production & Glu & Fruc & Suc & Mani & Malt & Lact \\
\hline 1 & S1 & - & - & - & + & - & + & + & + & + \\
\hline 2 & S2 & - & - & - & + & + & + & + & + & + \\
\hline 3 & S3 & - & - & - & + & + & + & + & + & + \\
\hline 4 & S4 & - & - & - & + & + & - & + & + & + \\
\hline 5 & S5 & - & - & - & + & + & - & - & + & + \\
\hline 6 & S6 & - & - & - & + & + & + & - & + & + \\
\hline 7 & S7 & - & - & - & + & + & + & - & + & + \\
\hline 8 & S8 & - & - & - & + & + & - & + & + & + \\
\hline 9 & 59 & - & - & - & + & + & + & - & + & - \\
\hline 10 & S10 & - & - & - & + & + & + & + & + & + \\
\hline
\end{tabular}

Glu glucose, Fruc fructose, Suc sucrose, Mani mannitol, Malt maltose, Lact lactose + Positive, - Negative 


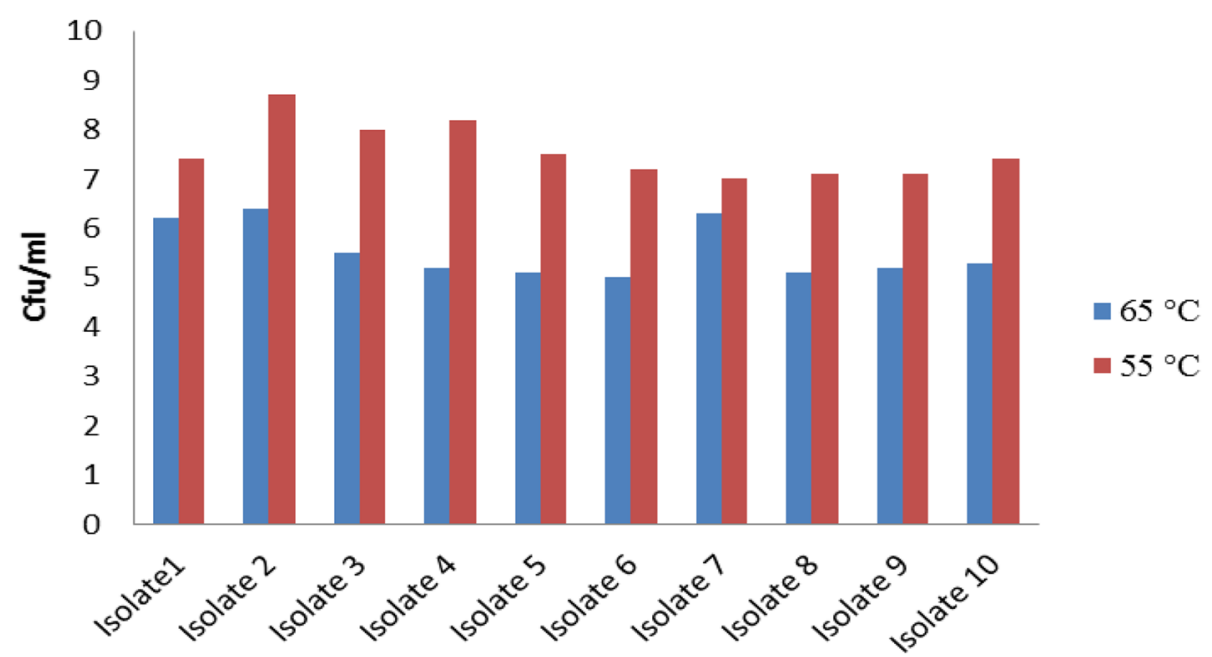

Fig. 1 Screening of the bacterial isolates for heat resistance

fermentation. All of the LAB were able to hydrolyze $\mathrm{CaCO}_{3}$ by forming clear zones around their colonies. Lactobacilli and Bifidobacteria are catalase-negative, do not produce indole and gas from glucose as described by Hoque et al. (2010). Sukumar and Ghosh (2010) found that Pediococcus sp. showed the same biochemical behavior as shown by isolate "S7," so it belonged to Pediococcus sp. Isolates belonging to the genera Lactobacillus, Bifidobacterium, and Pediococcus were also confirmed by fermentation behavior of isolates as described by Karna et al. (2007). Hence, isolates presumably belonged to the genera Lactobacillus, Bifidobacterium, and Pediococcus as indicated by morphological and biochemical characterization.

The most potent isolate (S2) based on different probiotics attributes was further subjected to identification based on 16S rRNA gene sequencing and was identified as Lactobacillus acidophilus (data not shown here).

\section{Screening for heat resistance}

Heat tolerance of the isolates at $55^{\circ} \mathrm{C}$ and $65^{\circ} \mathrm{C}$ was observed, and it was found that they showed marked variation (Fig. 1). Survival rates of isolates were higher at $55^{\circ} \mathrm{C}$ as compared to $65^{\circ} \mathrm{C}$. Among all the isolates, Lactobacillus acidophilus (S2) isolate showed good heat tolerance making it the most appropriate strain for incorporation in Mozzarella cheese. Ding and Shah (2007) also reported that heat treatment at $65^{\circ} \mathrm{C}$ was lethal to all tested lactic acid bacteria. In another study, Minervini et al. (2012) screened 18 probiotic strains for their heat tolerance and got two thermophilic strains that were able to survive heat treatment at 65 and $55^{\circ} \mathrm{C}$ for 10

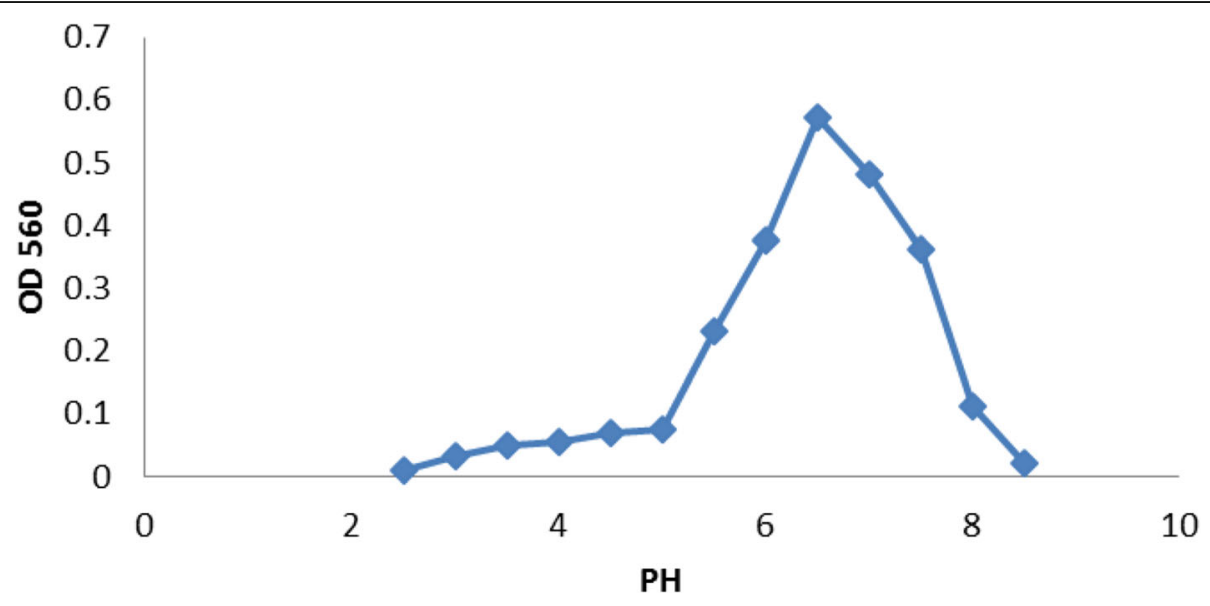

Fig. 2 Optimum growth pH of isolated Lactobacillus acidophilus (S2) 


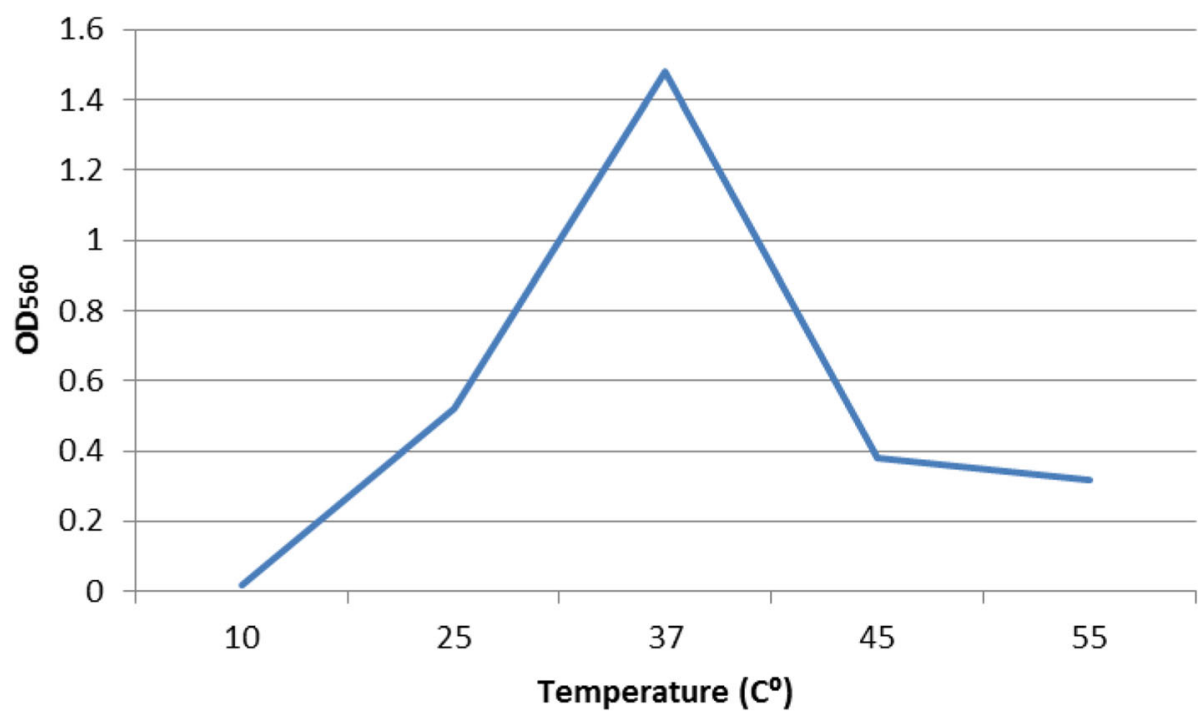

Fig. 3 Optimum growth temperature of isolated Lactobacillus acidophilus (S2)

min. Screening of heat-resistant probiotic strain is important for its use in hot stretched cheeses, as stretching of curd is done in hot brine.

\section{Physiological characterization of Lactobacillus acidophilus (S2)}

Heat-resistant Lactobacillus acidophilus (S2) was further characterized by physiological parameters. For this purpose, growth at different $\mathrm{pH}$ and temperature conditions was studied. Growth in the presence of $1-10 \% \mathrm{NaCl}$, $0.4 \%$ phenol tolerance, and $\mathrm{pH}$ variation in skimmed milk during $24 \mathrm{~h}$ of incubation was also analyzed.

The growth of bacteria changes dramatically as $\mathrm{pH}$ changes. Therefore, the growth of $L$. acidophilus was observed at different $\mathrm{pH}$ values between 2 and 8.5 to determine if it could grow under acidic as well as alkaline $\mathrm{pH}$ levels. Optimum growth of the strain was observed at pH 6.5 (Fig. 2). Previously, Hoque et al. (2010) had reported that Lactobacilli can grow in acidic as well as alkaline $\mathrm{pH}$ and observed maximum growth of Lactobacillus isolates between $\mathrm{pH}$ values of 5 and 6 .

For determining optimal growth temperature, growth at different temperatures, such as $10,25,37,45$, and $55^{\circ} \mathrm{C}$ was observed. It was found that optimum temperature for growth of Lactobacillus acidophilus (S2) was $37^{\circ} \mathrm{C}$ as maximum growth was observed at that temperature; Lactobacillus acidophilus (S2) was able to survive at $45-55^{\circ} \mathrm{C}$, exhibiting thermophilic behavior while no growth was observed at $10^{\circ} \mathrm{C}$ (Fig. 3). Patil and Vishwanath (2012) reported that a Lactobacillus sp. isolated from cheese showed maximum growth at $37^{\circ} \mathrm{C}$ although growth was also observed at $45^{\circ} \mathrm{C}$.

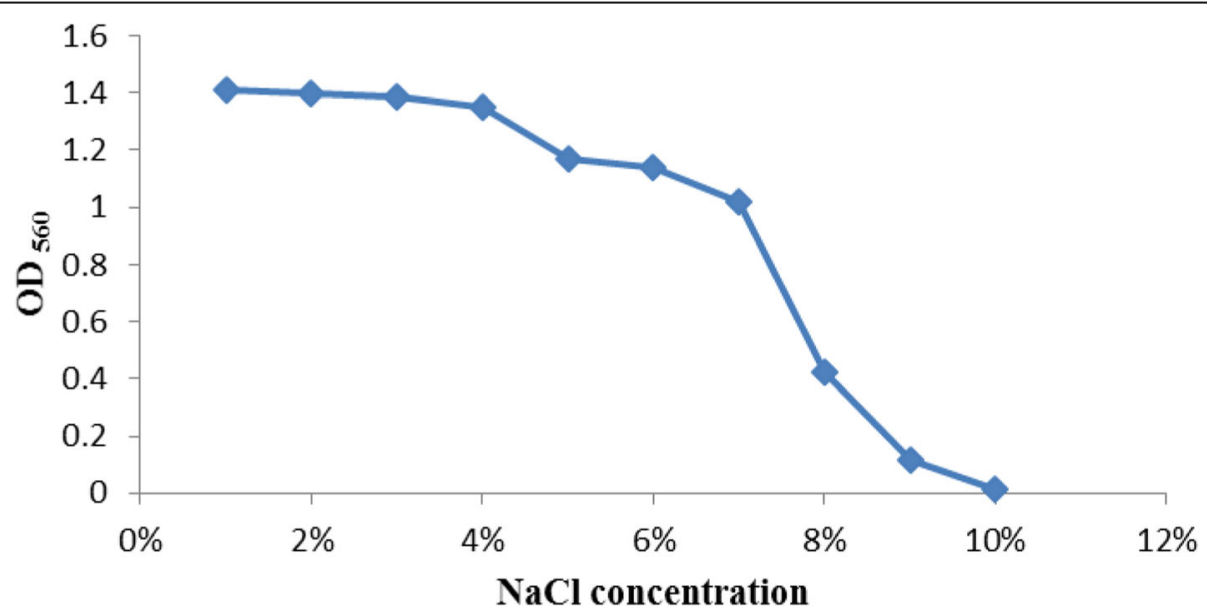

Fig. $4 \mathrm{NaCl}$ tolerance profile of the isolated Lactobacillus acidophilus (S2) 


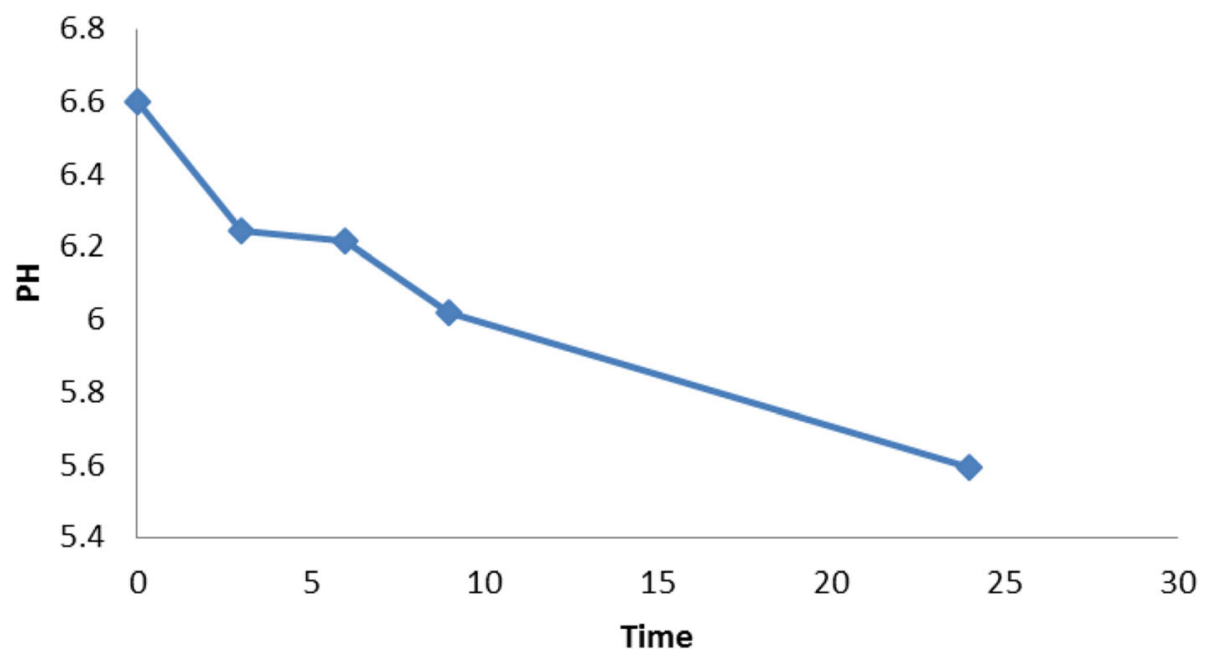

Fig. 5 Variation in skim milk's pH during incubation at $37^{\circ} \mathrm{C}$

Tolerance to different $\mathrm{NaCl}$ concentrations by the isolate was also assessed as $\mathrm{NaCl}$ is an inhibitory substance in terms of the growth of microbes. It was found that Lactobacillus acidophilus (S2) was able to tolerate high concentrations of $\mathrm{NaCl}$ ranging from 1 to $9 \%$. At $1 \%$ concentration of $\mathrm{NaCl}$, very good growth was observed which gradually declined to no growth at $10 \% \mathrm{NaCl}$ concentration (Fig. 4). Pancheniak and Soccol (2005) isolated a potential probiotic Lactobacillus sp. from the gastrointestinal tract of a swine which was able to tolerate $\mathrm{NaCl}$ concentration between 4 and $8 \%$. Phenol has bacteriostatic activity and inhibits the growth of bacteria. For this purpose, the inhibitory effects of phenol on Lactobacillus sp. revealed that Lactobacillus acidophilus (S2) was a potential probiotic strain and could grow in the presence of $0.4 \%$ phenol (data not included). Similar findings were previously reported by Hoque et al. (2010).

Lactobacillus acidophilus (S2) was inoculated in skimmed milk to elucidate the $\mathrm{pH}$ variation of skimmed milk with time. It was discovered that the $\mathrm{pH}$ of the skimmed milk decreased with an increase in time of incubation, and this was due to organic acid production. The $\mathrm{pH}$ of skimmed milk decreased from 6.6 to $5.5 \mathrm{pH}$ units after $24 \mathrm{~h}$ of incubation (Fig. 5). Hoque et al. (2010) studied the $\mathrm{pH}$ variations in skimmed milk inoculated by Lactobacilli and reported that after $24 \mathrm{~h}, \mathrm{pH}$ of skimmed milk changed from the initial 6.6 to $5.09 \mathrm{pH}$ units after $24 \mathrm{~h}$ of incubation. In the present study, Lactobacillus acidophilus (S2) also decreased the $\mathrm{pH}$ of skimmed milk.

Table 4 Acidic pH tolerance of Lactobacillus acidophilus (S2)

\begin{tabular}{|c|c|c|c|c|}
\hline $\mathrm{pH}$ & Time (hours) & Control & L. acidophilus (isolate S2) & Survival percentage (\%) \\
\hline \multirow[t]{2}{*}{1} & 1 & $231\left(10^{-4}\right)$ & - & $0 \pm 0$ \\
\hline & & $231\left(10^{-4}\right)$ & - & \\
\hline \multirow[t]{6}{*}{2} & 1 & $201\left(10^{-4}\right)$ & 118 & $57.2 \pm 3.5$ \\
\hline & & $201\left(10^{-4}\right)$ & 113 & \\
\hline & 2 & $185\left(10^{-5}\right)$ & 89 & $46 \pm 3.5$ \\
\hline & & $185\left(10^{-5}\right)$ & 84 & \\
\hline & 4 & $171\left(10^{-6}\right)$ & 70 & $38.5 \pm 5.6$ \\
\hline & & $171\left(10^{-6}\right)$ & 62 & \\
\hline \multirow[t]{6}{*}{3} & 1 & $256\left(10^{-4}\right)$ & 186 & $71.8 \pm 2.8$ \\
\hline & & $256\left(10^{-4}\right)$ & 182 & \\
\hline & 2 & $153\left(10^{-5}\right)$ & 101 & $64.05 \pm 3.5$ \\
\hline & & $153\left(10^{-5}\right)$ & 96 & \\
\hline & 4 & $198\left(10^{-6}\right)$ & 69 & $36.36 \pm 4.2$ \\
\hline & & $198\left(10^{-6}\right)$ & 75 & \\
\hline
\end{tabular}


Table 5 Antibiotic resistance of Lactobacillus acidophilus (S2)

\begin{tabular}{lll}
\hline Antibiotic & Concentration of antibiotic $(\mu \mathrm{g})$ & Response \\
\hline Chloramphenicol & 30 & $\mathrm{R}$ \\
Erythromycin & 5 & $\mathrm{R}$ \\
Tetracycline & 5 & $\mathrm{R}$ \\
Oxacillin & 1 & $\mathrm{R}$ \\
Vancomycin & 30 & $\mathrm{R}$ \\
\hline R
\end{tabular}

$R$ resistant

\section{Assessment of probiotic potential}

Lactobacilli strains are the most proclaimed potential probiotics (FAO/WHO 2002) and are widely used in food and non-food preparations.

Tolerance to acidic $\mathrm{pH}$ is the first criterion to select probiotics. The effect of acidic $\mathrm{pH}$ on the Lactobacillus acidophilus (S2) revealed that it was able to tolerate $\mathrm{pH}$ levels of 2 to 3 , while no growth was observed at $\mathrm{pH} 1.0$ (Table 4). Tolerance to acidic $\mathrm{pH}$ and bile salts is important for probiotic bacteria as they have to pass through the gastrointestinal tract and have exposure to bile salts in the intestine. Bile salt tolerance is the second most important criterion to select probiotics. Lactobacillus acidophilus (S2) showed good tolerance to $2 \%$ bile salt. Bile salt tolerance was $282 \mathrm{CFU} / \mathrm{mL}$ for control and $156 \mathrm{CFU} / \mathrm{mL}$ for Lactobacillus acidophilus (S2); the survival percentage was 55.3\%. Corzo and Gilliland (1999) reported that the determination of survival of bacteria in acidic $\mathrm{pH}$ is a more accurate way to analyze their survival through the gastrointestinal tract. Bile salt tolerance is also important for probiotic bacteria as it helps probiotics to colonize the gastrointestinal tract (Pisano et al. 2014). Up to $0.3 \%$ is the average bile salt concentration faced by probiotic bacteria in the intestine which may reach to extremes. Pinto et al. (2006) reported that Lactobacillus johnsonii LA-1 showed better survival ability at acidic $\mathrm{pH}$ as compared to commercial Bifidobacteria.

Many lactic acid bacteria are resistant to different antibiotics. Lactobacillus sp. are referred to as sensitive to antibiotics when the zone of inhibition is $\geq 21 \mathrm{~mm}$ while $\leq 15 \mathrm{~mm}$ diameter zone of inhibition has been considered as resistant (Kacem et al. 2006). Lactobacillus acidophilus (S2) showed antibiotic resistance against chloramphenicol, tetracycline, gentamycin, and vancomycin (Table 5). Patil and Vishwanath (2012) reported

Table 6 Antimicrobial activity of Lactobacillus acidophilus (S2)

\begin{tabular}{ll}
\hline Test pathogens & Diameter of zone of inhibition $(\mathrm{mm}) \pm \mathrm{SD}$ \\
\hline Salmonella thyphimurium & $11.50 \pm 1.0$ \\
Escherichia coli & $9.00 \pm 0.3$ \\
Staphylococcus aureus & $12.00 \pm 1.0$
\end{tabular}

Each value is mean of three replicates; \pm indicates the standard deviation from mean value; values are significant $(p \leq 0.05)$
Table 7 Survival of Lactobacillus acidophilus (S2) in free and encapsulated form

\begin{tabular}{lll}
\hline $\begin{array}{l}\text { Storage period } \\
\text { (days) }\end{array}$ & $\begin{array}{l}\text { Free Lactobacillus sp. } \\
(\mathrm{CFU} / \mathrm{mL})\end{array}$ & $\begin{array}{l}\text { Encapsulated Lactobacillus } \\
\text { sp. (CFU/mL) }\end{array}$ \\
\hline 1 & $1.10 \times 10^{7}$ & $3.41 \times 10^{8}$ \\
5 & $2.64 \times 10^{7}$ & $2.34 \times 10^{8}$ \\
10 & $2.10 \times 10^{7}$ & $2.12 \times 10^{8}$ \\
15 & $3.21 \times 10^{7}$ & $2.54 \times 10^{8}$ \\
\hline
\end{tabular}

that the antibiotic resistance of lactic acid bacteria can be therapeutic and preventive against different intestinal pathogens and would help to balance the normal intestinal flora of patients whose normal microbial flora have been disturbed due to intake of antibiotics. Among all antibiotics, vancomycin is the most important as it is one of the latest antibiotics that is broadly effective against clinical infections (Devriese and Butaye 1998). According to safety aspects, Mathur and Singh (2005) reported that an increase in antibiotic resistance in intestinal flora is alarming and might be due to the extensive use of antibiotics in animal foods.

The antimicrobial effect of Lactobacillus acidophilus (S2) was observed against Salmonella thyphimurium, Escherichia coli, and Staphylococcus aureus (Table 6). The diameter of the zone of inhibition against Salmonella thyphimurium was $10.00 \pm 1.0$, while the zone of inhibition against Escherichia coli was $8.50 \pm$ 0.3 . The selected isolate exhibited antimicrobial activity against enteric pathogens; therefore, it could be used for prevention of certain intestinal infections such as diarrhea. The findings of current study were in agreement with the previously documented studies (Pan et al. 2009).

Lactobacillus acidophilus (S2) was found to be nonhemolytic as there was no change in the color of blood agar around the Lactobacillus acidophilus (S2) colony. Thus, Lactobacillus acidophilus (S2) was nonhemolytic and was a potential probiotic bacterium. Lactic acid bacteria show antimicrobial activity against gastrointestinal pathogens due to the production of bacteriocins which are peptides that have antimicrobial activity (Liasi et al. 2009). Antimicrobial activity of lactic acid bacteria may be due to $\mathrm{H}_{2} \mathrm{O}_{2}$, organic acids, bacteriocins, or inhibitory substances of metabolites (Testa et al. 2003). Zhang et al. (2008) reported that Lactobacilli exhibit good anti-microbial activity against intestinal pathogens. Ehrmann et al. (2002) reported that the anti-microbial activity is due to acid production which is a major factor. Fayol-Messaoudi et al. (2005) also revealed that antimicrobial activity of lactic acid bacteria is due to low $\mathrm{pH}$ caused by acid production. Patil and Vishwanath (2012) reported that in their study that Lactobacillus sp. was non- 
Table 8 Safety assessment of probiotic cheese

\begin{tabular}{llll}
\hline \multicolumn{2}{l}{ Coliform count (CFU/mL) } & & \\
\hline Storage period (days) & Control cheese (CFU/mL) & Cheese A (free Lactobacillus sp.) (CFU/mL) & Cheese B (encapsulated Lactobacillus sp.) (CFU/mL) \\
\hline 1 & ND & ND & ND \\
5 & ND & ND & ND \\
10 & 2.4 & ND & ND \\
15 & 3.7 & 1.1 & 1.5 \\
\hline
\end{tabular}

All three types of cheeses were stored at $4{ }^{\circ} \mathrm{C}$

$N D$ not detected

hemolytic; therefore, Lactobacillus acidophilus was found to be potentially safe to use as a probiotic.

\section{Cheese production and characterization}

Three types of cheese, cheese A, cheese B, and control cheese, were made: cheese A with free cells of Lactobacillus acidophilus (S2), cheese B with encapsulated cells of Lactobacillus acidophilus (S2), and control cheese with no added probiotic. These cheeses were stored at $4{ }^{\circ} \mathrm{C}$ and examined for microbiological, compositional, and organoleptic analysis.

Mozzarella cheese is a hot stretched cheese involving kneading treatment. Probiotic loss can occur during the production of cheese and for this reason $\sim 10^{10} \mathrm{CFU} / \mathrm{mL}$ of Lactobacillus acidophilus (S2) was added in milk after coagulation for maintaining good bacterial count in cheese. Encapsulated Lactobacillus acidophilus (S2) showed better survival as compared to free cells of Lactobacillus acidophilus (S2) (Table 7); the free count of Lactobacillus acidophilus (S2) was $1.10 \times 10^{7} \mathrm{CFU} /$ $\mathrm{mL}$, while encapsulated Lactobacillus acidophilus (S2) count was $3.41 \times 10^{8} \mathrm{CFU} / \mathrm{mL}$ in cheese. Less loss of encapsulated bacteria was noted as compared to free cells of Lactobacillus acidophilus (S2). During 15 days of storage at $4{ }^{\circ} \mathrm{C}$, no loss in encapsulated and free Lactobacillus acidophilus (S2) was observed. No coliform was observed in cheese A containing free cells of probiotic strain and cheese B containing encapsulated Lactobacillus acidophilus (S2) as compared to control cheese (Table 8). Coliforms are common contaminants responsible for spoilage of Mozzarella cheese due to its high moisture and low salt content (Altieri et al. 2005; De Angelis et al. 2008; Sinigaglia et al. 2008). In cheese A and cheese $\mathrm{B}$, the added probiotic bacteria did not allow the growth of coliforms due to their antimicrobial activity as compared to control cheese. This may also have effect on the storage life of Mozzarella cheese. As previously reported, studies have also documented that the addition of probiotics in any food product, such as cheese and ice cream, increases the shelf-life of the product by suppressing the growth of coliforms mainly through bacteriocins production (Altieri et al. 2005; Minervini et al. 2012). Ding and Shah (2007) studied the effect of heat treatments on different lactic acid bacteria and reported that lactic acid bacteria tolerate harsher conditions in a better way when they are in encapsulated form. Ortakci et al. (2012) reported that bacterial count in hot stretched cheeses is high when bacteria are incorporated in encapsulated form as compared to free cells of bacteria because high temperature proves lethal for bacteria. According to safety aspects, it was found that the addition of probiotics increased the shelf-life of food products as Lactobacillus sp. did not allow the growth of coliforms due to their antimicrobial activity as has already been shown by Minervini et al. (2012).

Moisture content, $\mathrm{pH}, \mathrm{NaCl}$, and fat content of cheeses at day 1 during storage at $4{ }^{\circ} \mathrm{C}$ were determined. Moisture content of cheese A and cheese B was almost the same $(57.1 \% \pm 0.05)$ while the moisture content of control cheese was slightly higher, i.e., $60.1 \% \pm 0.05$. The $\mathrm{pH}$ values of cheese $\mathrm{A}$ and cheese $\mathrm{B}$ were almost the same (5.1 \pm 0.05 and $5.2 \pm 0.05$, respectively) while the $\mathrm{pH}$ value of control cheese was a little high $(5.5 \pm 0.05)$. Fat content was low in cheese B (15.6 \pm 0.1$)$ as compared to cheese A $(16.2 \pm 0.1)$, while the fat content of control cheese was found to be $12.2 \pm 0.1$. NaCl concentration was high in cheese $\mathrm{B}(1.5 \pm 0.3)$ as compared to cheese A $(1.3 \pm 0.3)$ (Table 9). An increase in $\mathrm{NaCl}$ concentration in cheese containing microencapsulated probiotics might be because of alginate. As alginate was

Table 9 Moisture content, $\mathrm{pH}, \mathrm{NaCl}$, and fat content of probiotic cheeses at day 1

\begin{tabular}{lllll}
\hline Cheese type & Moisture content (\%) & $\mathrm{pH}$ & $\mathrm{NaCl}(\%)$ & Fat content (\%) \\
\hline Control & $60.1 \pm 0.05$ & $5.5 \pm 0.05$ & $1.1 \pm 0.1$ & $12.2 \pm 0.1$ \\
Cheese A & $57.1 \pm 0.05$ & $5.1 \pm 0.05$ & $1.3 \pm 0.3$ & $16.2 \pm 0.1$ \\
Cheese B & $57.1 \pm 0.05$ & $5.2 \pm 0.05$ & $1.5 \pm 0.3$ & $15.6 \pm 0.1$ \\
\hline
\end{tabular}

Cheese stored at $4{ }^{\circ} \mathrm{C}$; Each value is mean of three replicates; \pm indicates the standard deviation from mean value; values are significant $(p \leq 0.05)$ 
Table 10 Organoleptic analysis of probiotic cheese

\begin{tabular}{|c|c|c|c|c|c|}
\hline Cheese types & Flavor & Creamy & Texture & Sour & Acceptability \\
\hline \multicolumn{6}{|c|}{ Organoleptic analysis at day 1} \\
\hline Control cheese & $1 \pm 0.6$ & $1.1 \pm 0.4$ & $1.3 \pm 0.5$ & $0.8 \pm 0.4$ & $1.05 \pm 0.2$ \\
\hline Cheese A & $2.2 \pm 0.7$ & $2.3 \pm 0.5$ & $1.7 \pm 0.5$ & $1.8 \pm 0.4$ & $2 \pm 0.2$ \\
\hline Cheese B & $1.8 \pm 0.4$ & $2.2 \pm 0.8$ & $1.7 \pm 0.5$ & $2.1 \pm 0.5$ & $1.95 \pm 0.2$ \\
\hline \multicolumn{6}{|c|}{ Organoleptic analysis at day 7} \\
\hline Control cheese & $1.3 \pm 0.5$ & $1.5 \pm 0.5$ & $1.3 \pm 0.5$ & $1.5 \pm 0.5$ & $1.4 \pm 0.1$ \\
\hline Cheese A & $2.8 \pm 0.4$ & $2.8 \pm 0.4$ & $2.6 \pm 0.5$ & $2.8 \pm 0.4$ & $2.7 \pm 0.1$ \\
\hline Cheese B & $2.7 \pm 0.5$ & $2.5 \pm 0.5$ & $2.8 \pm 0.5$ & $2.4 \pm 0.1$ & $2.65 \pm 0.1$ \\
\hline
\end{tabular}

Each value is mean of three replicates; \pm indicates the standard deviation from mean value; values are significant $(p \leq 0.05)$

used in the present study for microencapsulation purpose and slightly high level of $\mathrm{NaCl}$ was found in cheese $\mathrm{B}$ containing probiotic in encapsulated form. This observation is comparable to Ortakci et al. (2012). Minervini et al. (2012) who had studied the gross composition of control and probiotic Mozzarella cheese had reported that the moisture content and $\mathrm{pH}$ of probiotic Mozzarella cheese were low as compared to control cheese. Similar findings have been obtained in the present study.

Organoleptic analysis of cheeses was done at 1st and 7 th days of storage at $4{ }^{\circ} \mathrm{C}$ (Table 10). Cheese A and cheese $\mathrm{B}$ got the highest scores as compared to control cheese. The addition of probiotic bacteria enhanced the organoleptic properties of cheese. Overall, acceptability was same for cheese A and cheese B. Incorporations of probiotic in different types of cheeses have been studied by different researchers (Minervini et al. 2012; Shahab Lavasani et al. 2011; Albenzio et al. 2013). They found that the probiotic added cheeses possessed good sensory attributes such as flavor, aroma, and texture as compared to control cheese. Similar results were obtained in the present study. Gobbetti et al. (2010) reported that the enhancement of flavor was mainly due to the formation of free amino acid and volatile compounds. Additions of probiotics in food products, such as cheese, not only prolong their shelf-life but also increase the organoleptic properties of cheese making it a good delivery system for probiotics.

\section{Conclusion}

This study revealed that Lactobacillus acidophilus was the most efficient strain for the production of probiotic Mozzarella cheese. The present study also documents that the probiotic supplemented cheese possessed good sensory attributes as compared to non-probiotic added cheese. The use of probiotics in cheese not only prolonged the shelf-life of the cheese but also increased the organoleptic properties of the cheese and thus making it a good delivery system for probiotics.
Research involving human participants and/or animals Involvement of human participants.

\section{Authors' contributions}

HM conceived the idea and supervised the study. SY conducted the experiments and analyzed the data. SY and HM wrote the manuscript. $\mathrm{HH}$ reviewed and approved the final manuscript.

\section{Funding}

No funding was involved.

Ethics approval and consent to participate

Ethical approval was taken from the Institutional Bioethics Committee, GCU Lahore, and written informed consent was taken from study participants.

\section{Competing interests}

All authors declare no conflict of interests.

Received: 10 April 2020 Accepted: 10 July 2020

Published online: 25 September 2020

\section{References}

Albenzio M, Santillo A, Caroprese M, Braghieri A, Sevi A, Napolitano F (2013) Composition and sensory profiling of probiotic Scamorza ewe milk cheese. J Dairy Sci 96:792-800. doi: https://doi.org/10.3168/jds. 2012-6273

Altieri C, Scrocco C, Sinigaglia M, De Nobile MA (2005) Use of chitosan to prolong mozzarella cheese shelf-life. J Dairy 88, 2683-2688. https://doi.org/ 10.3168/jds.S0022-0302 (05)72946-5

Anal AK, Singh H (2007) Recent advances in microencapsulation of probiotics for industrial applications and targeted delivery. TFST 18(5):240-251 https://doi. org/10.1016/j.tifs.2007.01.004

AOAC (2000) Official Methods of Analysis. 17th Edition. The Association of Official Analytical Chemists, Gaithersburg

Astashkina AP, Khudyakova LI, Kolbysheva YV (2014) Microbiological quality control of probiotic products. Procedia Chemistry. Vol. 10: Chemistry and Chemical Engineering in XXI century, 10, pp.74-79. https://doi.org/10.1016/j. proche.2014.10.014

Bai AP, Ouyang Q (2006) Probiotics and inflammatory bowel diseases. Med J 82(968):376-378 10.1136\%2Fpgmj.2005.040899

Barakat OS, Ibrahim GA, Tawfik NF, El-Kholy WI, El-Rab GD (2011) Identification and probiotic characteristics of Lactobacillus strains isolated from traditional Domiati cheese. Int J Microbiol Res 3(1):59. https://pdfs.semanticscholar.org/5 c13/4dff273258450b578db78624ae2fb2c8f1cc.pdf

Benson JA, Flores AE, Baker CJ, Hillier SL, Ferrieri P (2002) Improved methods for typing nontypeable isolates of group B streptococci. Int J Med Microbiol 292(1):37-42. https://doi.org/10.1078/1438-4221-00188

Bujalance C, Jiménez-Valera M, Moreno E, Ruiz-Bravo A (2006) A selective differential medium for Lactobacillus plantarum. Int J Med Microbiol 1;66(3): 572-5. https://doi.org/10.1016/j.mimet.2006.02.005

Chen MJ, Chen KN (2007) Applications of probiotic encapsulation in dairy products. Encapsulation and controlled release technologies in food systems Wiley-Blackwell, USA 29:83-112. https://doi.org/10.1002/9780470277881.ch4. 
Corzo G, Gilliland SE (1999) Measurement of bile salt hydrolase activity from Lactobacillus acidophilus based on disappearance of conjugated bile salts. J Dairy Sci 82(3):466-414. https://doi.org/10.3168/jds.S00220302(99)75255-0

De Angelis M, de Candia S, Calasso MP, Faccia M, Guinee TP, Simonetti MC, Gobbetti M (2008) Selection and use of au tochthonous multiple strain cultures for the manufacture of high moisture traditional Mozzarella cheese. Int J Food Microbiol 125(2):123-32. https://doi.org/10.1016/j.ijfoodmicro.2008. 03.043

De Man JC, Rogosa DM, Sharpe ME (1960) A medium for the cultivation of lactobacilli. J Appl Bacteriol 23(1):130-135. https://doi.org/10.1111/j.13652672.1960.tb00188.x

Devriese LA, Butaye P (1998) Vancomycin susceptibility as an aid to the identification of lactobacilli. Lett Appl Microbiol 27(2):121. https://doi.org/10. 1046/j.1472-765x.1998.t01-1-00400.x

Ding WK, Shah NP (2007) Acid, bile, and heat tolerance of free and microencapsulated probiotic bacteria. J Food Sci 72(9): M446-M450. https:// doi.org/10.1111/j.1750-3841.2007.00565.x

Ehrmann MA, Kurzak P, Bauer J, Vogel RF (2002) Characterization of lactobacilli towards their use as probiotic adjuncts in poultry. Appl Microbiol 92(5):966975. https://doi.org/10.1046/j.1365-2672.2002.01608.x

Falagas ME, Betsi Gl, Tokas T, Athanasiou S (2006) Probiotics for prevention of recurrent urinary tract infections in women. Drugs 66(9):1253-1261. https:// doi.org/10.2165/00003495-200666090-00007

FAO/WHO Working Group Report (2002) Guidelines for the evaluation of probiotics in food. Ontario, Canada, London

Fayol-Messaoudi D, Berger CN, Coconnier-Polter MH, Lievin-Le Moal V, Servin $\mathrm{AL}$ (2005) pH-, Lactic acid-, and non-lactic acid-dependent activities of probiotic Lactobacilli against Salmonella enterica Serovar Typhimurium. Appl Environ Microbiol 71(10):6008-6013. https://doi.org/10.1128/AEM.71. 10.6008-6013.2005

Fortin MH, Champagne CP, St-Gelais D, Britten M, Fustier P, Lacroix M (2011) Effect of time of inoculation, starter addition, oxygen level and salting on the viability of probiotic cultures during Cheddar cheese production. Int Dairy J 21(2):75-82. https://doi.org/10.1016/j.idairyj.2010.09.007

Gobbetti M, Cagno RD, De Angelis M (2010) Functional microorganisms for functional food quality. Crit. Rev. Food Sci Nutr 50(8):716-727. https://doi.org/ 10.1080/10408398.2010.499770

Helene FM, Champagne CP, St-Gelais D, Britten M, Fustier P, Lacroix M (2011) Effect of time of inoculation, starter addition, oxygen level and salting on the viability of probiotic cultures during Cheddar cheese production. Int Dairy J 21(2):75-82. https://doi.org/10.1016/j.idairyj.2010.09.007.

Holt JG, Krieg NR, Sneath PH (1994) Bergey's manual of determinative bacterology. Williams and Wilkins 787 http://archives.umc.edu.dz/ handle/123456789/121739

Hoque MZ, Akter F, Hossain KM, Rahman MS, Billah MM, Islam KM (2010) Isolation, identification and analysis of probiotic properties of Lactobacillus spp. from selective regional yoghurts. World J Dairy Food Sci 5(1):39-46.

Jose NM, Bunt CR, Hussain MA (2015) Comparison of microbiological and probiotic characteristics of lactobacilli isolates from dairy food products and animal rumen contents. Microorganisms 3(2):198-212. https://doi.org/10. 3390/microorganisms3020198

Kacem M, Zadi-Karam H, Karam N (2006) Detection and characterization of a novel bacteriocin produced by Lactobacillus plantarum OL9 against Erwinia chrysanthemi strains. Nat Appl Sci Series. 21:159-171

Karami S, Roayaei M, Hamzavi H, Hassanzad-Azar H, Leila M, Rafieian-Kopaei M (2017) Isolation and identification of probiotic Lactobacillus from local dairy and evaluating their antagonistic effect on pathogens. Int J Pharm Investig (3):137-141. https://doi.org/10.4103/jphi.JPHI_8_17

Karna BKL, Emata OC (2007) Barraquio VL. Lactic acid and probiotic bacteria from fermented and probiotic dairy products SD 19:23-34

Krämer S, Bischoff SC (2006) Therapeutic possibilities of probiotics in antibioticrelated diarrhea. MMW Fortschr Med 148(35-36):28-30. https://doi.org/10. 1007/bf03364716

Lankaputhra WE, Shah NP (1996) A simple method for selective enumeration of Lactobacillus acidophilus in yogurt supplemented with L. acidophilus and Bifidobacterium spp. Milchwissenschaft 51:446-451

Lavasani AS, Ehsani MR, Mirdamadi S, Mousavi SM (2011) Effect of Bifidobacterium lactis on some physico-chemical and organoleptical properties of Lighvan cheese. Afr J Biotechnol 10(69):15600-15606. https://doi.org/10.5897/AJB11. 1826
Lee HM, Lee Y (2008) A differential medium for lactic acid-producing bacteria in a mixed culture. Lett Appl 46(6):676-681. https://doi.org/10.1111/j.1472-765X. 2008.02371.x

Liasi SA, Azmi TI, Hassan MD, Shuhaimi M, Rosfarizan M, Ariff AB (2009) Antimicrobial activity and antibiotic sensitivity of three isolates of lactic acid bacteria from fermented fish product, Budu. Malays Microbiol J 5(1):33-37

Mahrous H, El-Kholy WM, Elsanhoty RM (2014) Production of new synbiotic yoghurt with local probiotic isolate and oat and study its effect on mice. J Adv Dairy Res 24:1-7. https://doi.org/10.4172/2329-888X.1000121

Mathur S, Singh R (2005) Antibiotic resistance in food lactic acid bacteria-a review. Int J Food Microbiol 105(3):281-295. https://doi.org/10.1016/j. ijfoodmicro.2005.03.008

Mattila-Sandholm T, Myllärinen P, Crittenden R, Mogensen G, Fondén R, Saarela M (2002) Technological challenges for future probiotic foods. Int Dairy J 12(2 3):173-182. https://doi.org/10.1016/S0958-6946(01)00099-1

Minervini F, Siragusa S, Faccia M, Dal Bello F, Gobbetti M, De Angelis M (2012) Manufacture of Fior di Latte cheese by incorporation of probiotic lactobacilli. J Dairy Sci 95(2):508-20. https://doi.org/10.3168/jds.2011-4150

Naeem MA, llyas M, Haider S, Baig S, Saleem M (2012) Isolation characterization and identification of lactic acid bacteria from fruit juices and their efficacy against antibiotics. Pak J Bot 44(323):8 https://pdfs.semanticscholar.org/254 c/60e3654b49be58341a30d8e61fb9d4072f69.pdf

O'Flaherty S, Klaenhammer TR (2010) The role and potential of probiotic bacteria in the gut, and the communication between gut microflora and gut/host. Int Dairy J 20(4):262-8. https://doi.org/10.1016/j.idairyj.2009.11.011

Ortakci F, Broadbent JR, McManus WR, McMahon DJ (2012) Survival of microencapsulated probiotic Lactobacillus paracasei LBC-1e during manufacture of Mozzarella cheese and simulated gastric digestion. J Dairy Sci 95(11):6274-6281. https://doi.org/10.3168/jds.2012-5476

Pan X, Chen F, Wu T, Tang H, Zhao Z (2009) The acid, bile tolerance and antimicrobial property of Lactobacillus acidophilus NIT. Food Control 20(6): 598-602. https://doi.org/10.1016/j.foodcont.2008.08.019

Pancheniak ED, Soccol CR (2005) Biochemical characterization and identification of probiotic Lactobacillus for swine. B CEPPA 23(2). https://doi.org/10.1046/j. 1365-2672.2002.01608x

Patil LS, Vishwanath PP (2012) Assessment of probiotic potential of Lactobacillus sp. isolated from cheese and preparation of probiotic icecream. IJRAP 1;3(4).

Pinto MG, Franz CM, Schillinger U, Holzapfel WH (2006) Lactobacillus spp. with in vitro probiotic properties from human faeces and traditional fermented products. Int J Food Microbiol 109(3):205-214. https://doi.org/10.1016/j. ijfoodmicro.2006.01.029

Pisano MB, Viale S, Conti S, Fadda ME, Deplano M, Melis MP, Deiana M, Cosentino S (2014) Preliminary evaluation of probiotic properties of Lactobacillus strains isolated from Sardinian dairy products. BioMed res int 1-9. https://doi.org/10. $1155 / 2014 / 286390$

Sanders ME, Gibson GR, Gill HS, Guarner F (2007) Probiotics: their potential to impact human health. CAST Issue Paper 36:1-20 https://centaur.reading.ac. uk/13017/

Senter L, Pereira JQ, Vieira MA, Michielin EM, Tondo EC (2015) Isolation and characterization of Lactobacillus plantarum BLS29 as a potential probiotic starter culture for pork sausage production. Afr J Microbiol Res 9(32):18871895. https://doi.org/10.5897/AJMR2015.7606

Sheu TY, Marshall RT (1993) Microencapsulation of lactobacilli in calcium alginate gels. J Food Sci 54:557-561. https://doi.org/10.1111/j.1365-2621. 1993.tb04323.x

Shylaja R, Selvakumar D, Jagannath JH (2010) Isolation and identification of lactic acid bacteria from raw and fermented products and their antibacterial activity. IJLRST 2(6):42-46 http://recent-science.com/.../1732

Sinigaglia M, Bevilacqua A, Corbo MR, S. Pati, Nobile M. A. Del (2008) Use of active compounds for prolonging the shelf life of mozzarella cheese. Int Dairy J 18:624-630. https://doi.org/10.1016/j.idairyj.2007.11.022

Snedecor, G.W. and W.G. Cochran. 1980. Statistical Methods, 7th Edition, lowa State University, pp.32-43

Sukumar G, Ghosh AR (2010) Pediococcus spp.-a potential probiotic isolated from Khadi (an Indian fermented food) and identified by 165 rDNA sequence analysis. Afr J Food Sci 4(9):597-602 https://academicjournals.org/ajfs

Sulieman AM, Ali RA, Razig KA (2012) Production and effect of storage in the chemical composition of Mozzarella cheese. Int J Food Sci Nutr Eng 2(3):2126. https://doi.org/10.5923/j.food.20120203.02 
Testa MM, de Valladares RR, de Cardenas IL (2003) Antagonistic interactions among Fusobacterium nucleatum and Prevotella intermedia with oral lactobacilli. Res Microbiol 154(10):669-675. https://doi.org/10.1016/j.resmic. 2003.09.007

Weichselbaum E (2009) Probiotics and health: a review of the evidence. Nutr Bull 34(4):340-373. https://doi.org/10.1111/j.1467-3010.2009.01782.x

Yerlikaya O (2014) Starter cultures used in probiotic dairy product preparation and popular probiotic dairy drinks. J Food Sci Technol 34(2):221-229. https:// doi.org/10.1590/fst.2014.0050

Zhang R, Yang L, Cai JC, Zhou HW, Chen GX (2008) High-level carbapenem resistance in a Citrobacter freundii clinical isolate is due to a combination of KPC-2 production and decreased porin expression. J Med Microbiol 57(3): 332-337. https://doi.org/10.1099/jmm.0.47576-0

Zinedine A, Faid M (2007) Isolation and characterization of strains of Bifidobacteria with probiotic proprieties in vitro. J Dairy Food Sci 2(1):28-34 https://www.semanticscholar.org/paper/lsolation-and-characterization-ofstrains-of-with-Zinedine-Faid/99f7ea19301fd8e4106314bcab0b7238c41bc4a3

\section{Publisher's Note}

Springer Nature remains neutral with regard to jurisdictional claims in published maps and institutional affiliations.

Ready to submit your research? Choose BMC and benefit from:

- fast, convenient online submission

- thorough peer review by experienced researchers in your field

- rapid publication on acceptance

- support for research data, including large and complex data types

- gold Open Access which fosters wider collaboration and increased citations

- maximum visibility for your research: over $100 \mathrm{M}$ website views per year

At $\mathrm{BMC}$, research is always in progress.

Learn more biomedcentral.com/submissions 